\title{
Corrosion Behavior Analysis of Plasma-assited PVD Coated Ti-6Al-4V alloy in 2 M NaOH Solution
}

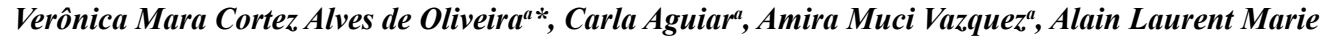 \\ Robin $^{a}$, Miguel Justino Ribeiro Barboza ${ }^{a}$ \\ ${ }^{a}$ Escola de Engenharia de Lorena, Universidade de São Paulo - USP, Polo Urbo-Industrial Gleba AI-6, \\ Fazenda Mondezir, Lorena, SP, Brazil
}

Received: December 03, 2015; Revised: November 08, 2016; Accepted: January 04, 2017.

\begin{abstract}
The work aims the study of the corrosion behavior of nitride plasma-assisted PVD coated Ti-6Al$4 \mathrm{~V}$ alloy in $2 \mathrm{M} \mathrm{NaOH}$ at 25 and $60^{\circ} \mathrm{C}$, using open-circuit potential (OCP) versus time measurements, potentiodynamic polarization and electrochemical impedance spectroscopy (EIS). The uncoated Ti6Al-4V alloy showed a passive behavior. The TiN and TiAlN/TiAlCrN coated Ti-6Al-4V alloy also presented a passive behavior and the corrosion potential remained at the same range when compared with the potential of the uncoated alloy. The TiN hard coating showed a superior corrosion resistance, which was evidenced by lower corrosion current densities and higher impedance values. The increase in temperature decreased the corrosion resistance of both uncoated and coated alloy in $\mathrm{NaOH}$.
\end{abstract}

Keywords: Titanium, Polarization, EIS

\section{Introduction}

Various industries (like aerospace, biomedical, military, automotive and chemical) use titanium and its alloys. Due to their properties, they work in extreme conditions such as high temperature, corrosive environments and high strength ${ }^{1,2}$.

About $80 \%$ of the global titanium amount produces aerospace parts such as gas turbines, wings and other load-bearing components. The other part acts in corrosive environments such as body fluid (pins, stents and artificial heart valves production), salty water (heat exchangers) and chemical media (compressor engine parts); and high temperatures ${ }^{1,3,4}$.

Titanium alloys manufacture biomedical materials because of their low modulus, biocompatibility and superior corrosion resistance when compared to cobalt alloys and stainless steel. To provide better osseointegration, these pieces are usually treated with a bioinert material - hydroxyapatite ${ }^{1}$.

Coating deposition on titanium alloys attracts attention by acting as barriers to the metallic diffusion. The corrosion products release metallic ions in the biological environment and may cause toxicity, allergy and mutagenicity ${ }^{5}$. Most of the transition metals form binary or ternary nitrides with good mechanical, tribological, protective and biocompatibility properties. In recent years, nitrides as TiN, $\mathrm{ZrN}$, TiAlN, $\mathrm{NbN}$, TaN and $\mathrm{VN}$ are used as protective layers against wear and corrosion in order to increase the prostheses and implants lifetime ${ }^{5}$. Cubillos et al. ${ }^{6}$ reported $\mathrm{ZrN}$ coated steel corrosion in $\mathrm{NaCl}$ solution due to pitting. The authors inform current densities ranged between $10^{-10}$ and $10^{-8} \mathrm{~A} / \mathrm{cm}^{2}$.
Fenker and colleagues ${ }^{7}$ studied $\mathrm{NbN}$ coated steel corrosion behavior and concluded that this coating increased steel corrosion behavior, closing pores with corrosion products during potenciodynamic test. Ma et al. ${ }^{8}$ showed TaN coated Cr12MoV polarization curves and informed potential value higher $\left(-370 \mathrm{mV}_{\mathrm{SCE}}\right.$ against $\left.-412 \mathrm{mV}_{\mathrm{SCE}}\right)$ and passive current density value lower $\left(5 \times 10^{-3} \mathrm{~A} / \mathrm{cm}^{2}\right.$ against $\left.4.5 \times 10^{-2} \mathrm{~A} / \mathrm{cm}^{2}\right)$ than substrate values.

This paper is part of a series of electrochemical analyses that studied the corrosion behavior of TiN and TiAlN/TiAlCrN coated Ti-6Al-4V alloy, deposited by plasma-assisted PVD, in different corrosive environments and at different temperatures. Initially, the corrosion behavior of uncoated and coated Ti-6Al-4V alloy was studied in $2 \mathrm{M} \mathrm{HCl}$ and 3.5 $\%$ wt $\mathrm{NaCl}$ solutions at 25,60 and $80{ }^{\circ} \mathrm{C}^{9,10}$. These studies, which was reported in the literature ${ }^{9,10}$, showed that in $\mathrm{HCl}$ solution Ti-6Al-4V alloy demonstrated an active behaviour with an active-passive transition and coated $\mathrm{Ti}-6 \mathrm{Al}-4 \mathrm{~V}$ alloy presented a passive behaviour. In $\mathrm{NaCl}$ solution, Ti-6Al-4V uncoated and coated alloy showed a passive behavior under all conditions. In both corrosive solutions, coated Ti-6Al$4 \mathrm{~V}$ alloy showed a superior corrosion resistance with lower corrosion current densities and higher impedance values compared to the uncoated sample. It was also reported that increasing temperature decreased the corrosion resistance of the uncoated and coated Ti-6Al-4V alloy.

The present work aimed to investigate the corrosion behavior of TiN and TiAlN/TiAlCrN coated and uncoated Ti-6Al-4V alloy in $2 \mathrm{M} \mathrm{NaOH}$ at 25 and $60{ }^{\circ} \mathrm{C}$ for biomedical and chemical applications.

* e-mail: veronicamcaoliveira@gmail.com 


\section{Materials and methods}

The microstructure of Ti-6Al-4V alloy (5.980 wt.\% Al, 0.005 wt. $\%$ C, 0.200 wt. $\%$ Fe, 0.001 wt. $\%$ H, 0.005 wt. $\%$ N, 0.001 wt. $\%$ O, 4.070 wt.\% V and 89.738 wt.\% Ti) was studied.

TiN and TiAlN/TiAlCrN based coatings (coated condition) were deposited on a total of 12 (twelve) specimens. The coatings were deposited by cathodic arc plasma assisted physical vapour deposition (PVD). The chamber has six cathodes or targets, which act as a highly-emitting area and present negative voltage relative to the chamber wall. Targets release the cathode material in the nitrogen plasma cloud where the reaction took place generating nitrides that were deposited on the substrate surface. TiN based coating is a single layer, which reached $2.2 \mu \mathrm{m}$ of thickness (Figure 1a). TiAlN/TiAlCrN based coating is a multilayer, with 11 interfaces (TiAlN layers - $540 \mathrm{~nm}$, TiAlCrN layers $-217 \mathrm{~nm}$ of thickness) and $6 \mu \mathrm{m}$ of thickness (Figure 1b).
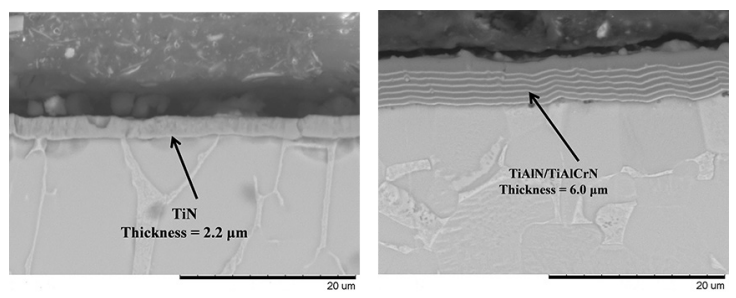

Figure 1. SEM images of PVD coated Ti-6Al-4V alloy microstructure (cross section): a) TiN and b) TiAlN/TiAlCrN.

Cilindrical specimens of $8 \mathrm{~mm}$ diameter and $17 \mathrm{~mm}$ in length were hot mounted in Teflon holders. The exposed uncoated surface area $\left(0.5 \mathrm{~cm}^{2}\right)$ was ground with $\mathrm{SiC}$ papers until 1200 grit, rinsed with distilled water and dried before transferring to the corrosive solution. The coated samples were not ground in order to maintain the coating integrity. The solution was $2 \mathrm{M} \mathrm{NaOH}$, which was prepared using P.A reagents and distilled water. The temperatures were maintained at 25 and $60{ }^{\circ} \mathrm{C}$. For the latter temperature, a thermostatic bath (FISATOM mod. 550) was used. The counter electrode was a platinum $(\mathrm{Pt})$ foil. All potentials were referred to a saturated calomel electrode (SCE). The corrosion behavior of uncoated and coated Ti-6Al-4V alloys was studied using open-circuit potential vs. time (for three hours), electrochemical impedance spectroscopy (EIS) and potentiodynamic polarization. All measurements were performed using an Electrochemical Interface SOLARTRON mod. 1287 A and a Frequency Response Analyser SOLARTRON mod. 1260 A, controlled by the Ecorr/Zplot SOLARTRON mod. $125587 \mathrm{~S}$ software. Data acquisition and analyses were performed using the same software.

\section{Results and discussion}

Figure 2 shows the open circuit potential versus time curve $(\mathrm{OCP})$ obtained at room temperature $\left(25^{\circ} \mathrm{C}\right)$ and $60^{\circ} \mathrm{C}$ in $2 \mathrm{M} \mathrm{NaOH}$ solution of uncoated, TiN and TiAlN/TiAlCrN coated Ti-6Al-4V alloy. It demonstrates that the potential of uncoated Ti-6Al-4V alloy at $25{ }^{\circ} \mathrm{C}$ became more positive with time and tends to stabilize. This behavior suggests formation and growth of a passivating film. However, at 60 ${ }^{\circ} \mathrm{C}$, the potential increases, reaches a maximum and moves towards negative potential, to also stabilize. This behavior suggests formation of a passivating film, but with less stability.
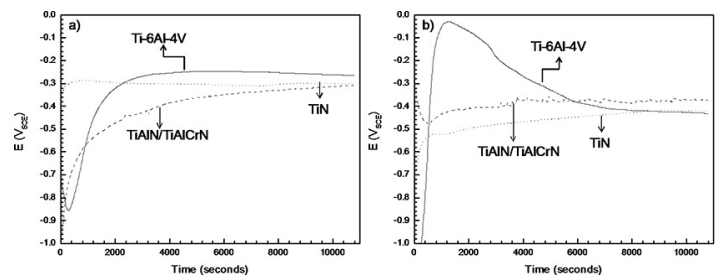

Figure 2. Open circuit potential vs. time for uncoated, TiN, and TiAlN/TiAlCrN coated Ti-6Al-4V alloy, in $2 \mathrm{M} \mathrm{NaOH}$ : a) at $25^{\circ} \mathrm{C}$, b) at $60^{\circ} \mathrm{C}$.

Figure 3 shows the anodic polarization curves of uncoated, TiN and TiAlN/TiAlCrN coated Ti-6Al-4V alloy in $\mathrm{NaOH}$ solution obtained at 25 and $60{ }^{\circ} \mathrm{C}$. These curves represent the response in current form at a potential ranged from -0.5 to $2 \mathrm{~V}_{\mathrm{SCE}}$ against $\mathrm{E}_{\text {corr }}$. They tell us which is the material spontaneous behavior (if occurs spontaneous passivation or passivation under anodic polarization). They also inform us the passivating film stability and characteristic curve values such as $i_{\text {corr }}$ and $i_{\text {pass }}$.
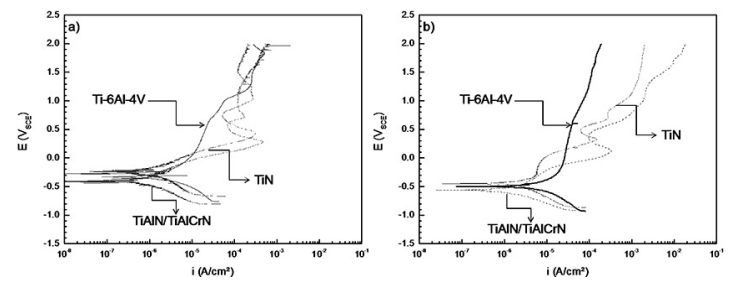

Figure 3. Potentiodynamic polarization curves for uncoated, TiN, and TiAlN/TiAlCrN coated Ti-6Al-4V alloy in $2 \mathrm{M} \mathrm{NaOH}$ : a) at $25^{\circ} \mathrm{C}$, b) at $60{ }^{\circ} \mathrm{C}$.

Table 1 presents the main electrochemical parameters obtained from Figures 2 and Figure 3.

- Corrosion potential $\left(\mathrm{E}_{\text {corr }}\right)$ - indicate the material nobility;

- $\quad$ Null-current potential $\left(\mathrm{E}_{\mathrm{i}=0}\right)$;

- Corrosion and passivation current densities ( $i_{\text {corr }}$ and $\left.i_{\text {pass }}\right)$ - these parameters are the material corrosion rate, so high current densities values means lower material resistance;

- Tafel slopes $\left(\beta_{\mathrm{a}}, \beta_{\mathrm{c}}\right)$ - ensure linearity in $\mathrm{i}_{\text {corr }}$ measures.

Figure 2 analysis together with titanium's Pourbaix diagram $^{11}$ (Figure 4) indicates that the corrosion potential $\left(-0.4 \mathrm{~V}_{\mathrm{SHE}}<\mathrm{E}_{\text {corr }}<-0.6 \mathrm{~V}_{\mathrm{SHE}}\right)$ in $2 \mathrm{M} \mathrm{NaOH}$ solution, $\mathrm{pH} 10$, is in the passivation region, which means passive behavior. 
Table 1. Open circuit potential and polarization electrochemical parameters of uncoated, TiN and TiAlN/TiAlCrN coated Ti-6Al-4V alloy measured in at 25 and $60^{\circ} \mathrm{C}$.

\begin{tabular}{|c|c|c|c|c|c|c|c|}
\hline \multirow[b]{2}{*}{ Temperature $\left({ }^{\circ} \mathrm{C}\right)$} & \multirow[b]{2}{*}{ Sample } & \multirow[b]{2}{*}{$\begin{array}{c}\mathrm{E}_{\text {corr }} \\
\left(\mathrm{V}_{\mathrm{SCE}}\right)\end{array}$} & \multirow[b]{2}{*}{$\begin{array}{c}\mathrm{E}_{\mathrm{i}=0} \\
\left(\mathrm{~V}_{\mathrm{SCE}}\right)\end{array}$} & \multirow[b]{2}{*}{$\begin{array}{c}\mathrm{i}_{\text {corr }} \\
\left(\mathrm{A} / \mathrm{cm}^{2}\right)\end{array}$} & \multicolumn{3}{|c|}{ Parameters } \\
\hline & & & & & $\begin{array}{c}\beta_{\mathrm{c}} \\
\text { (mV/decade) }\end{array}$ & $\begin{array}{c}\beta_{\mathrm{a}} \\
\text { (mV/decade) }\end{array}$ & $\begin{array}{c}\mathrm{i}_{\text {pass }} \\
\left(\mathrm{A} / \mathrm{cm}^{2}\right)^{*}\end{array}$ \\
\hline \multirow{3}{*}{25} & Ti-6Al-4V & -0.264 & -0.323 & $6.2 \times 10^{-7}$ & -93 & 102 & $2.1 \times 10^{-5}$ \\
\hline & $\mathrm{TiN}$ & -0.301 & -0.233 & $2.1 \times 10^{-7}$ & -192 & 192 & - \\
\hline & TiAlN/TiAlCrN & -0.309 & -0.409 & $6.3 \times 10^{-7}$ & -109 & 100 & - \\
\hline \multirow{3}{*}{60} & Ti-6Al-4V & -0.432 & -0.499 & $2.2 \times 10^{-6}$ & -80 & 112 & $3.6 \times 10^{-5}$ \\
\hline & $\mathrm{TiN}$ & -0.372 & -0.449 & $1.3 \times 10^{-6}$ & -76 & 114 & - \\
\hline & TiAlN/TiAlCrN & -0.422 & -0.564 & $1.3 \times 10^{-6}$ & -267 & 219 & - \\
\hline
\end{tabular}

* measured in the middle of passive region.

Under anodic polarization, Figure 3 a displays passive behavior of uncoated, TiN and TiAlN/TiAlCrN coated alloy at room temperature $\left(\mathrm{i}<9 \times 10^{-4} \mathrm{~A} / \mathrm{cm}^{2}\right)$. At $60^{\circ} \mathrm{C}$, Figure $3 \mathrm{~b}$ shows active behavior at coated condition under anodic polarization.

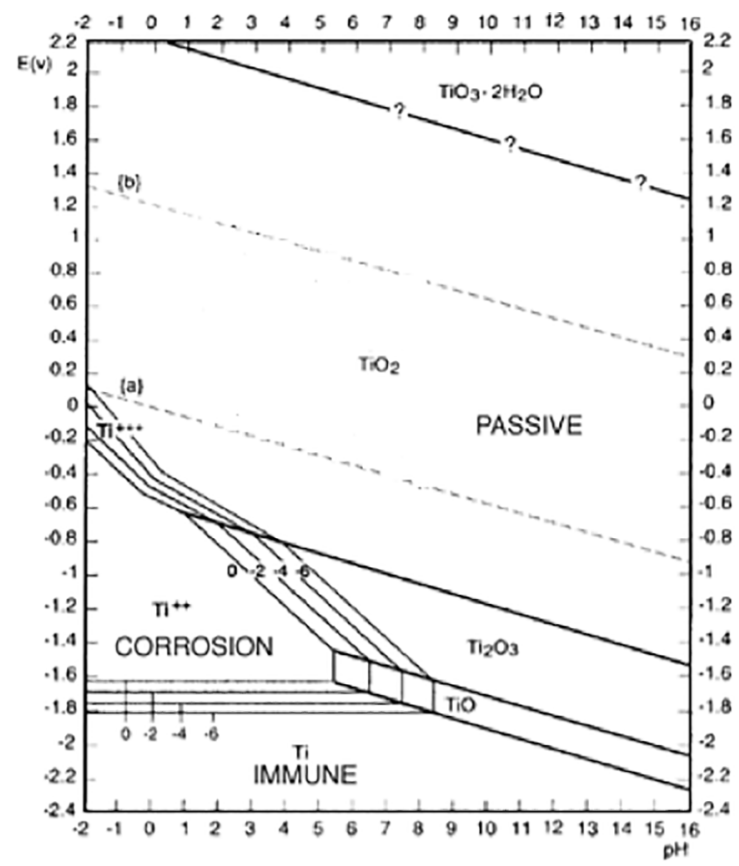

Figure 4. Pourbaix diagram of titanium $\left(\mathrm{V}_{\mathrm{SHE}} \mathrm{vs} \mathrm{pH}\right)^{11}$.

For the uncoated alloy, the anodic current density increased from null-current potential at about $-0.323 \mathrm{~V}_{\mathrm{SCE}}$ (Figure 3a) and -0.499 $\mathrm{V}_{\mathrm{SCE}}$ (Figure 3b) and sustained this behavior for higher potentials due to $\mathrm{TiO}_{2}$ based film formation. $\mathrm{TiO}_{2}$ delays titanium dissolution. The peak at 1.2 $\mathrm{V}_{\mathrm{SCE}}$, showed in Figure 3a, was referred to transpassivation. The null-current potential should be more negative than the $\mathrm{E}_{\text {corr }}$, because cathodic polarization tends to reduce surface oxides and make the surface less noble. Table 1 shows this trend. The anodic current density of coated alloys showed a behavior similar to one reported by Lunarska et $a l^{12}$ at both temperatures. Where, in a study about TiN coated steel corrosion behavior in $\mathrm{NaOH}$ solution, at anodic potentials, the current increased until transpassivation happened. Increasing temperature reduced the corrosion resistance in all experimental conditions.

Even with the prior grinding process, titanium reacts with oxygen and form a $\mathrm{TiO}_{2}$ based film. When the alloy immerses in a corrosive solution and remains at high potentials, the superficial film (formed by air) stabilizes on surface without undergoing dissolution. That means a more stable and protective film in corrosive solution. A material that behaves in this way is called spontaneously passive and this behavior has been observed by other authors who studied corrosion in $\mathrm{NaOH}$ solution.

$\mathrm{E}_{\text {corr }}$ values of this present work at uncoated condition were $-0.264 \mathrm{~V}_{\mathrm{SCE}}$ at $25^{\circ} \mathrm{C}$ and $-0.432 \mathrm{~V}_{\mathrm{SCE}}$ at $60^{\circ} \mathrm{C}$. These results agree with Pjescic and collaborators ${ }^{13}$, who studied titanium's behavior in concentrated $\mathrm{NaOH}$ solutions, ranging from 1 to $5 \mathrm{M}$ at $25^{\circ} \mathrm{C}$. Shahba et al. ${ }^{14}$ studied the electrochemical behavior of pure titanium and Ti-6Al-4V alloy in $\mathrm{NaOH}$ solutions at concentrations ranging from 0.5 to $0.001 \mathrm{M}$. They, however, found $\mathrm{E}_{\text {corr }}$ values ranged between -0.958 and $-0.735 \mathrm{~V}_{\mathrm{SCE}}$ for pure titanium and between -0.858 to $-0.367 \mathrm{~V}_{\mathrm{SCE}}$ for Ti-6Al-4V alloy.

According Figure 2, TiN coated alloy sustained the potential, especially at $25^{\circ} \mathrm{C}$. At $60^{\circ} \mathrm{C}$, the potential begins high, falls and stabilizes at the same potential of uncoated Ti-6Al-4V. TiAlN/TiAlCrN coated alloy imitated TiN coated alloy behavior; except for OCP curve at $60^{\circ} \mathrm{C}$ that displays potential drops during the test, typical of a defective layer. According to Rossi et al. ${ }^{15}$, the stability of nitride based coatings in corrosive media is due to their chemical inertness, which is normal for ceramic structures. Figure 5 shows the surface of the TiN and TiAlN/TiAlCrN coated alloy before potentiodynamic polarization.

$\mathrm{TiO}_{2}$ is formed spontaneously on the surface of Ti-6Al-4V alloy when immersed in $\mathrm{NaOH}$ according to the following anodic reaction $^{11,13}$ :

$$
\mathrm{Ti}+4 \mathrm{OH}^{-}-4 e \rightarrow \mathrm{TiO}_{2}+2 \mathrm{H}_{2} \mathrm{O}
$$

The cathodic reaction is related to the oxygen reduction ${ }^{14}$. According to Hefny et al. and Pjescic et al. ${ }^{13,16}, \mathrm{TiO}_{2}$ can be dissolved in alkaline solutions. However, the concentration 

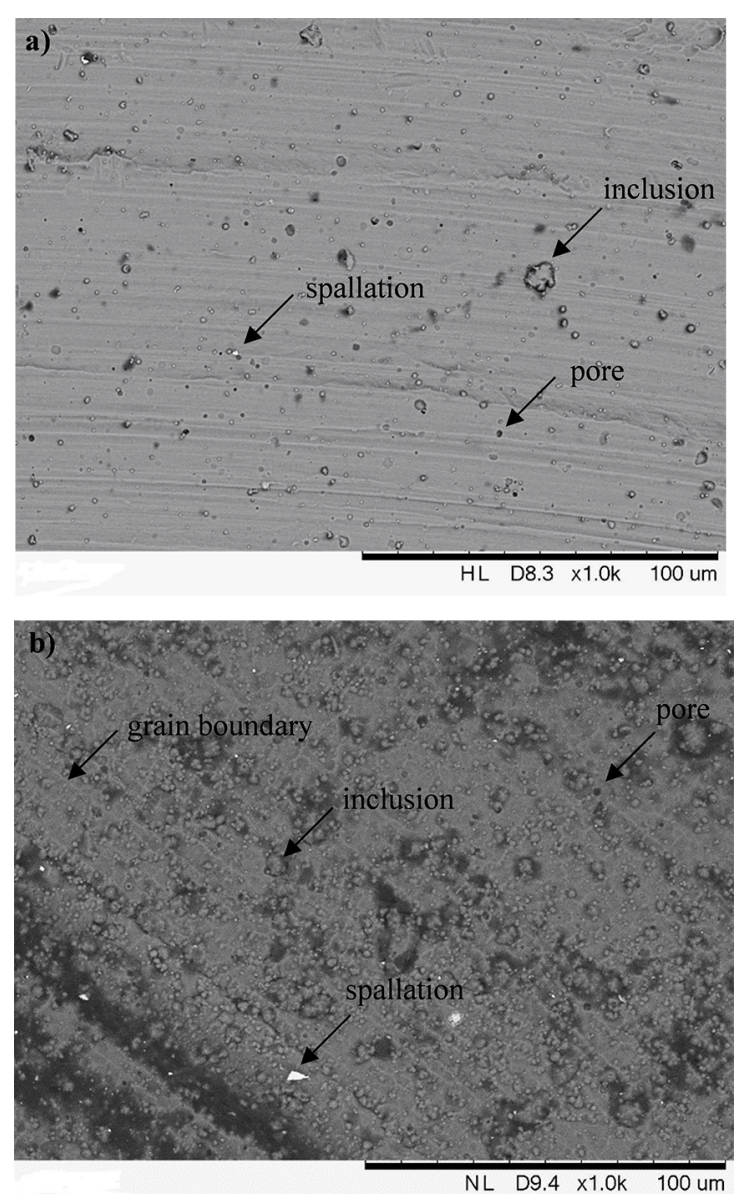

Figure 5. SEM images of PVD coated Ti-6Al-4V alloy surface before corrosion: a) TiN and b) TiAlN/TiAlCrN.

and temperature of such solutions are decisive for this reaction occurs. That is, $\mathrm{TiO}_{2}$ turn into titanate, as shown in the following reaction:

$$
\mathrm{TiO}_{2}+2 \mathrm{NaOH} \rightarrow \mathrm{Na}_{2} \mathrm{TiO}_{3}+\mathrm{H}_{2} \mathrm{O}
$$

Finally, at coated condition, Pohrelyuk ${ }^{17}$ described that when titanium nitrides behaves passively, it becomes an oxynitride, which is actively dissolved and oxidized to $\mathrm{TiO}_{2}$. This study, therefore, considers that under all experimental conditions it behaved passively due to stabilization (rather than dissolution) of $\mathrm{TiO}_{2}$ at room temperature.

Electrochemical impedance spectroscopy measures ions flow resistance through the solution and working electrode. This measurement is done via a sine disturbance in potential and is read as lagged current in a characteristic phase angle. The Equations 1 and 2 correspond to the disturbance in potential and to the response in current ${ }^{18,19}$.

$$
\begin{gathered}
E=E_{o} \sin \omega t \\
I=I_{o} \sin \omega t+\phi
\end{gathered}
$$

where $\mathrm{E}$ is the oscillating voltage, $\mathrm{E}_{0}$ is the amplitude of the oscillating voltage, $\mathrm{I}$ is the oscillating current, $\mathrm{I}_{0}$ is the amplitude of the oscillating current, $\omega$ is the angular frequency of disturbance and $\phi$ is the phase angle ${ }^{19}$.

Electrochemical impedance spectroscopy reflects the dielectric behavior, the oxi-reduction reactions and the mass transfer in the electrochemical interface (EI). Electrical and chemical properties of the corrosive solution and electrode material are related with the behavior of a specific EI. We adjust the impedance measurements using a equivalent electrical circuit that describes an EI. The EI's capacitive response usually comes from a non-ideal capacitor. Thus, a constant phase element (CPE) replaces pure capacitance according to Equation $3^{18-20}$.

$$
Z_{C P E}=\left[Y_{O}(j \omega)^{n}\right]^{-1}
$$

where $Y_{0}\left[\mathrm{~F} \cdot \mathrm{cm}^{-2}\right]$ and $\mathrm{n}(\mathrm{n} \leq 1)$ are adjustable parameters. If the surface acts as an ideal capacitor, $n$ is equal to one $(n=1)$, and $\mathrm{Y}_{0}$ will be identical to capacitance $\mathrm{C}^{20}$. We proposed two electrical circuit models for the conditions studied:

a) Uncoated Ti-6Al-4V:

Uncoated Ti-6Al-4V alloy behaved passively in $\mathrm{NaOH}$ solution indicating that the $\mathrm{TiO}_{2}$ based layer is stable in the corrosive medium. This layer is made of a porous outer part and a compact inner one ${ }^{21}$. Thus, the equivalent circuit proposed in this present work for uncoated alloy has two time constants. The first time constant is related to outer porous layer and the second one is related to compact inner layer. The equivalent circuit and its components are: $\mathrm{R}_{\mathrm{s}}$ as the corrosive solution resistance, $\mathrm{R}_{\mathrm{g}}$ the outer porous layer resistance, $\mathrm{C}_{\mathrm{g}}$ the outer porous layer pseudo-capacitance, $\mathrm{R}_{\mathrm{p}}$ the compact inner layer resistance and $\mathrm{C}_{\mathrm{p}}$ the compact inner layer pseudo-capacitance ${ }^{22,23}$. The pseudo-capacitance represents superficial heterogeneities ${ }^{23}$.

b) Coated TiN and TiAlN/TiAlCrN Ti-6Al-4V alloy:

Both TiN and TiAlN/TiAlCrN behaved passively. Nitride based coating are inert in any corrosive environment. The partial protective character of the nitride layers is due to the deposition method (PVD) that produces coatings with defects (pores, cracks, grain boundaries) ${ }^{24,25}$. The coated alloy behaved according to the electrical equivalent circuit model with two time constants with the following elements: $\mathrm{R}_{\mathrm{s}}$ corresponds to the corrosive solution resistance; $R_{c}$ represents the defective coating (pores, cracks, grain boundaries) resistance to charge transfer; $\mathrm{R}_{\mathrm{ct}}$ represents the charge transfer resistance at the coating/substrate interface. $\mathrm{C}_{\mathrm{c}}$ and $\mathrm{C}_{\mathrm{dl}}$ represent the pseudo-capacitances at solution/coating and coating/substrate interfaces, respectively ${ }^{24-27}$.

Figure 6 shows the equivalent circuit and its components for uncoated and coated conditions.

Figure 7 shows Nyquist plots of uncoated Ti-6Al-4V alloy in $2 \mathrm{M} \mathrm{NaOH}$ solution at 25 to $60^{\circ} \mathrm{C}$.

Figure 8 shows Bode diagrams of uncoated Ti-6Al-4V alloy at 25 and $60{ }^{\circ} \mathrm{C}$ in $2 \mathrm{M} \mathrm{NaOH}$. 


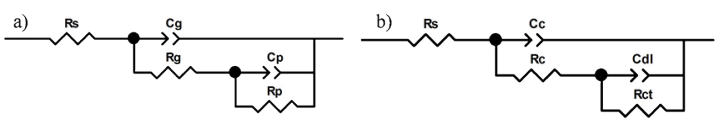

Figure 6. Electrical equivalent circuit proposed for: a) the uncoated Ti-6Al-4V alloy, b) the coated Ti-6Al-4V alloy, in $\mathrm{NaOH}$ solution.

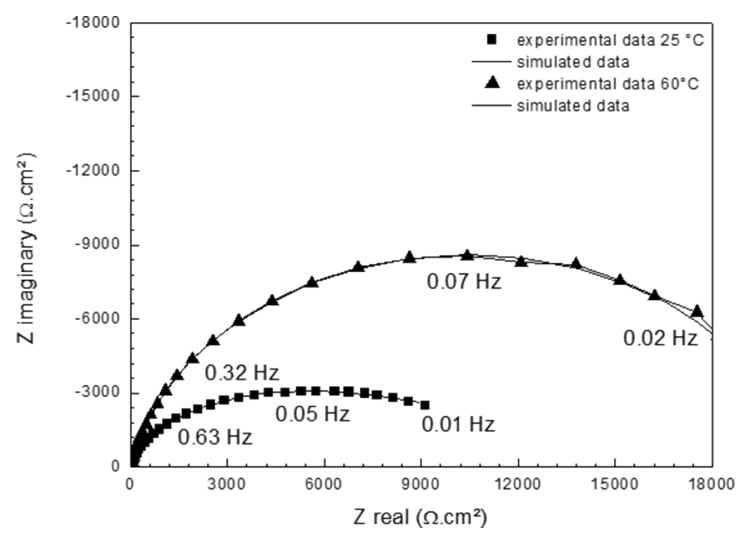

Figure 7. Nyquist diagram of uncoated Ti-6Al-4V alloy in $2 \mathrm{M}$ $\mathrm{NaOH}$ at 25 and $60^{\circ} \mathrm{C}$.
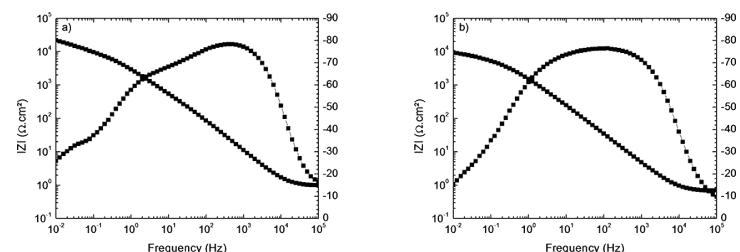

Figure 8. Bode diagrams of uncoated Ti-6 Al-4V alloy in $2 \mathrm{M}$ $\mathrm{NaOH}:$ a) at $25, \mathrm{~b})$ at $60^{\circ} \mathrm{C}$.

Figures 9 and Figure 10 show the Nyquist plots of TiN and TiAlN/TiAlCrN coated Ti-6Al-4V alloy in $2 \mathrm{M} \mathrm{NaOH}$, at 25 and $60{ }^{\circ} \mathrm{C}$.

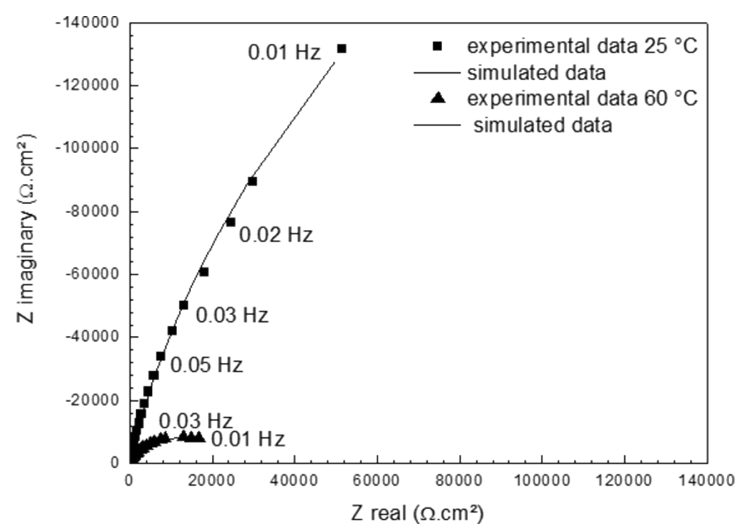

Figure 9. Nyquist diagram of TiN coated Ti-6Al-4V alloy in $2 \mathrm{M}$ $\mathrm{NaOH}$ at 25 and $60{ }^{\circ} \mathrm{C}$.

Figures 11 and Figure 12 show Bode diagrams of TiN and TiAlN/TiAlCrN coated Ti-6Al-4V alloy in $2 \mathrm{M} \mathrm{NaOH}$, at 25 and $60{ }^{\circ} \mathrm{C}$.

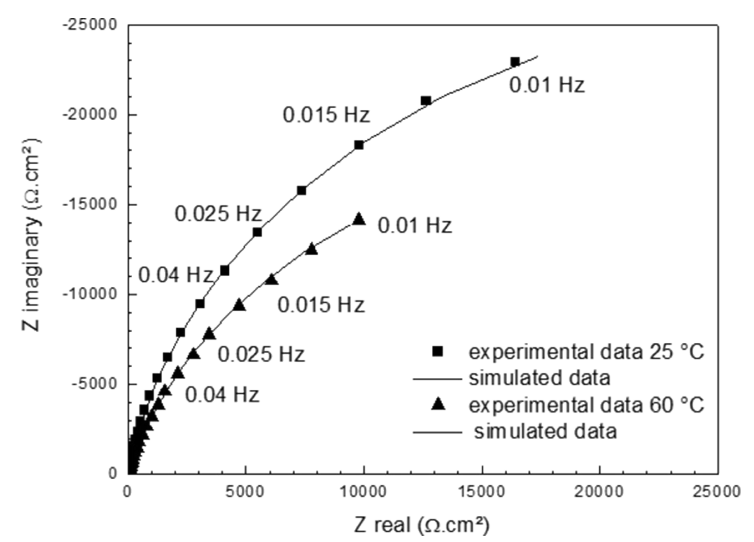

Figure 10. Nyquist diagram of TiAlN/TiAlCrN coated Ti-6Al-4V alloy in $2 \mathrm{M} \mathrm{NaOH}$ at 25 and $60^{\circ} \mathrm{C}$.
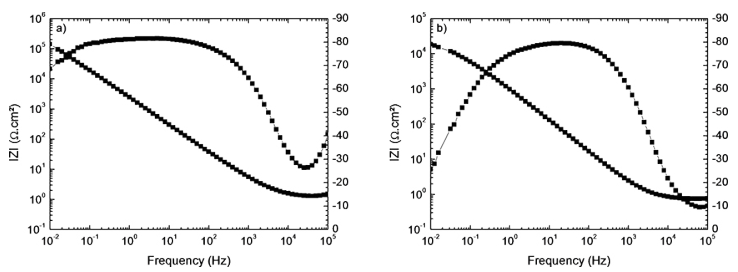

Figure 11. Bode diagrams of TiN coated Ti-6Al-4V alloy in $2 \mathrm{M}$ $\mathrm{NaOH}:$ a) at $25, \mathrm{~b}$ ) at $60^{\circ} \mathrm{C}$.
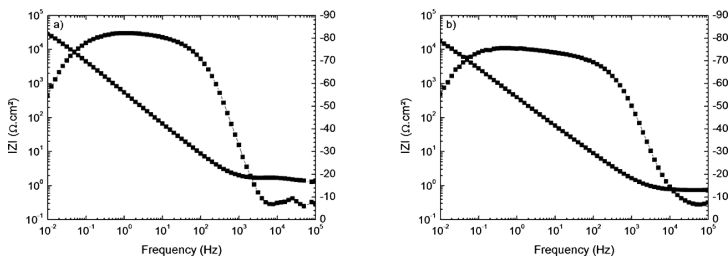

Figure 12. Bode diagrams of TiAlN/TiAlCrN coated Ti-6Al-4V alloy in $2 \mathrm{M} \mathrm{NaOH}:$ a) at $25, \mathrm{~b}$ ) at $60^{\circ} \mathrm{C}$.

Table 2 shows the impedance parameters. They were calculated according to the adjustments made by the equivalent circuit model of two time constants for all experimental conditions.

Increasing temperature decreases the diameter of the semicircles that means decrease in the polarization resistance, i.e., lower corrosion resistance. Souza and Robin ${ }^{28}$ in a study about concentration and temperature influence on the corrosion behavior of titanium alloys in sulfuric acid also observed a decrease of the semicircles of the Nyquist diagram with the increase of $25^{\circ} \mathrm{C}$ for $50^{\circ} \mathrm{C}$.

Electrochemical impedance is a complex combination solution resistance of the interface capacitance, resistance to charge transfer and mass spectroscopy. At high frequencies the solution resistance predominates; while, at low frequencies, the charge transfer and mass becomes the main contribution to the impedance ${ }^{29}$. In all solutions the alloy behaved according to the equivalent circuit model of two time constants. In corrosive process $\mathrm{NaOH}$ formed a dense film inner and a second one outer, but porous. According to Alves et al. ${ }^{22}$, 
Table 2. EIS data of uncoated, TiN, and TiAlN/TiAlCrN coated Ti-6Al-4V alloy obtained by equivalent electrical circuit models of two time constants.

\begin{tabular}{|c|c|c|c|c|c|c|c|c|}
\hline \multirow[b]{2}{*}{ Samples } & \multirow[b]{2}{*}{ Temperature $\left({ }^{\circ} \mathrm{C}\right)$} & \multicolumn{7}{|c|}{ Parameters } \\
\hline & & $\begin{array}{c}\mathrm{CPE}_{\mathrm{p}} \\
\left(\mathrm{F} \cdot \mathrm{cm}^{-2}\right)\end{array}$ & $\mathrm{n}_{\mathrm{p}}$ & $\begin{array}{c}\mathrm{CPE}_{\mathrm{g}} \\
\left(\mathrm{F} . \mathrm{cm}^{-2}\right)\end{array}$ & $\mathrm{n}_{\mathrm{g}}$ & $\begin{array}{c}\mathrm{R}_{\mathrm{s}} \\
\left(\Omega \cdot \mathrm{cm}^{2}\right)\end{array}$ & $\begin{array}{c}\mathrm{R}_{\mathrm{g}} \\
\left(\Omega \cdot \mathrm{cm}^{2}\right)\end{array}$ & $\begin{array}{c}\mathrm{R}_{\mathrm{p}} \\
\left(\Omega \cdot \mathrm{cm}^{2}\right)\end{array}$ \\
\hline \multirow{3}{*}{ Ti-6Al-4V } & 25 & $8.7 \times 10^{-5}$ & 0.45 & $3.2 \times 10^{-5}$ & 0.91 & 0.91 & 189.0 & $4.4 \times 10^{4}$ \\
\hline & 60 & $6.2 \times 10^{-5}$ & 0.92 & $1.1 \times 10^{-4}$ & 0.60 & 0.64 & 1.9 & $1.0 \times 10^{4}$ \\
\hline & & $\begin{array}{c}\mathrm{CPE}_{\mathrm{c}} \\
\left(\mathrm{F} \mathrm{cm}^{-2}\right)\end{array}$ & $\mathrm{n}_{\mathrm{c}}$ & $\begin{array}{c}\mathrm{CPE}_{\mathrm{dl}} \\
\left(\mathrm{F} \cdot \mathrm{cm}^{-2}\right)\end{array}$ & $\mathrm{n}_{\mathrm{dl}}$ & $\begin{array}{c}\mathrm{R}_{\mathrm{s}} \\
\left(\Omega \cdot \mathrm{cm}^{2}\right)\end{array}$ & $\begin{array}{c}\mathrm{R}_{\mathrm{c}} \\
\left(\Omega \cdot \mathrm{cm}^{2}\right)\end{array}$ & $\begin{array}{c}\mathrm{R}_{\mathrm{tc}} \\
\left(\Omega \cdot \mathrm{cm}^{2}\right)\end{array}$ \\
\hline \multirow{2}{*}{ TiN } & 25 & $2.8 \times 10^{-5}$ & 0.76 & $5.0 \times 10^{-5}$ & 0.94 & 0.20 & 1.6 & $8.9 \times 10^{5}$ \\
\hline & 60 & $6.2 \times 10^{-5}$ & 0.66 & $1.6 \times 10^{-4}$ & 0.90 & 0.77 & 0.8 & $2.3 \times 10^{4}$ \\
\hline \multirow{2}{*}{ TiAlN/TiAlCrN } & 25 & $1.0 \times 10^{-6}$ & 1.00 & $3.4 \times 10^{-4}$ & 0.90 & 1.33 & 0.3 & $6.0 \times 10^{4}$ \\
\hline & 60 & $4.8 \times 10^{-4}$ & 0.84 & $5.8 \times 10^{-5}$ & 0.90 & 0.71 & 129.0 & $4.6 \times 10^{4}$ \\
\hline
\end{tabular}

the layer that forms on the alloy Ti-6Al-4V is essentially $\mathrm{TiO}_{2}$, whether it is dense or porous.

The impedance results for all experimental conditions are in accordance with the potentiodynamic polarization, i.e., corrosion current density increasing $\left(\mathrm{i}_{\text {corr }}\right)$ means resistance to charge transfer $\left(\mathrm{R}_{\mathrm{ct}}\right)$, or compact inner layer resistance $\left(R_{p}\right)$ decreasing when temperature rises.

Analyzing the resistance of uncoated Ti-6Al-4V, $R_{p}$ values are higher than $R_{g}$ values. The inner dense layer controls the Ti-6Al-4V corrosion resistance. However, the $\mathrm{R}_{\mathrm{g}}$ estimate the porosity degree of the outer layer. $\mathrm{R}_{\mathrm{g}}$ higher values are related to less porous layers and vice versa ${ }^{21}$.

Table 3 summarizes electrochemical impedance values found in other studies about titanium corrosion behavior ${ }^{23,30-33}$.

Table 3 shows that is very difficult to compare the impedance results with other authors as these results may vary in a wide range. Gheetha et al. ${ }^{34}$ studied the influence of the microstructure and of alloying elements on corrosion behavior. They found different behaviors for different microstructures of a titanium alloy (Ti-13Nb-13Zr) in Ringer's solution. They observed that the quenched sample showed superior corrosion resistance due to uniform distribution of alloying elements in the different phases. The present work adopt an $\alpha+\beta$ alloy with lamellar microstructure, known as Widmansttäten morphology.

In the Bode diagrams, $Z$ modulus or absolute impedance value $(|Z|)$ and the phase angle $(\theta)$ is plotted against the frequency logarithm. If $\theta$ is equal to $-90^{\circ}$, the electrode behaves as a capacitor; if $\theta$ equals $0^{\circ}$, the electrode behaves as a resistance. In general, in the regions at low and high frequencies ( $\mathrm{f}<10 \mathrm{~Hz}$ or $\mathrm{f}>100 \mathrm{kHz}$ ), the phase angle approaches to $0^{\circ}$. For intermediate frequencies $(0.1<\mathrm{f}<100$ $\mathrm{kHz}$ ) the phase angle remains close to $-90^{\circ}$, indicating that the system resistance is controlled by surface polarizing of the working electrode. The higher is the range of intermediate frequency values close to $-90^{\circ}$, more stable is the passivating film 19,31

Ti-6Al-4V alloy showed nearly ideal capacitive behavior at the two studied temperatures (Figures 8, 11 and 12). Remaining in broad bands of intermediate frequency with a maximum phase angle close to $-90^{\circ}$ (at $25^{\circ} \mathrm{C} \approx-80^{\circ}$; at $60^{\circ} \mathrm{C} \approx-75^{\circ}$ ); and in $\log |\mathrm{Z}| \mathrm{x} \log$ frequency plots, the slope is about -1 . The results agree with other previous reports. Kumar et al. ${ }^{35}$ and Wang et al. ${ }^{36}$, who study Ti-6Al-4V electrochemical properties found $\log |Z| \times \log$ frequency plots slope close to -1 and the maximum phase angles between $-70^{\circ}$ and $-85^{\circ}$.

The $n$ values obtained from the $\log |\mathrm{Z}| \mathrm{x} \log$ frequency slope ranged between $0.45<n<1.0$ and agrees with Grips et al..$^{37}$, Liu et al. ${ }^{38}$ and Wan et al. ${ }^{39}$ findings.

Alloying elements adition in binary nitrides of transition metals, such as $\mathrm{Al}$ and $\mathrm{Cr}$, controls micropore size and density, improves the hardness and fracture toughness and increases corrosion and wear resistance ${ }^{37}$. A multilayer coating improves corrosion behavior when compared with a simple coating because of the increased coating thickness, which leads to statistical decrease of defects possibility through the coating (pores). If a coating is composed of different structured layers, phases electrochemical potentials will be different. Thus, corrosion penetration towards substrate is

Table 3. EIS measurments of titanium alloys.

\begin{tabular}{|c|c|c|c|}
\hline Referências & Meio de corrosão & Material & $\mathrm{R}\left(\Omega \mathrm{cm}^{2}\right)$ \\
\hline MANHABOSCO et al..$^{23}$ & PBS & Ti-6Al-4V & $1.4 \times 10^{6}$ \\
\hline BARRANCO et al. ${ }^{30}$ & Hank & Ti-6Al-4V & $1.5 \times 10^{7}$ \\
\hline VASILESCU et al..$^{31}$ & Ringer & Ti-6Al-4V1Zr & $5.2 \times 10^{5}$ \\
\hline CONTU et al. ${ }^{32}$ & $\mathrm{NaOH} 2 \mathrm{M}$ & Ti-6Al-4V & $6.5 \times 10^{3}$ \\
\hline DELGADO-ALVARADO et al..$^{33}$ & $3,5 \%$ p. $\mathrm{NaCl}$ & $\gamma-\mathrm{TiAl}$ & $2.5 \times 10^{6}$ \\
\hline
\end{tabular}


reduced due to current flow in the coating ${ }^{38}$. However, in the present work, we observed that the multilayer $\mathrm{E}_{\text {corr }}$ values were slightly affected by differences in the microstructure of the layer. Furthermore, TiAlN/TiAlCrN coated Ti-6Al-4V alloy suffered spallation in all studied temperatures at the end of polarization test.

It is known that the aluminum atom concentration in the multilayer studied here is greater than the titanium concentration. According Grips et al..$^{37}$, Al concentration increasing lead to improved corrosion resistance. However, when $\mathrm{Al}$ concentration value is higher than 50 at. \%, coating adhesion and hardness decrease. Kovalev et al. ${ }^{40}$ reported a study about alloying elements addition impact on TiN mechanical properties. They concluded that both aluminum amount and defects percentage in microstructure influence coating stability. Grips and colleagues ${ }^{37}$ informed that a multilayer prevents a direct path between the corrosive solution and the substrate, as an interlayer serves as a defects (micropores) block of the above one. In this present work, the blocking effect was negligible and allowed the corrosive solution reaching the substrate. Possible reasons, besides defects number increase by aluminum incorporation to nitride is: multilayer and interlayer thickness (total thickness $=6 \mu \mathrm{m}$, TiAlN $=540 \mathrm{~nm}$, TiAlCrN $=217 \mathrm{~nm}$ ) and interfaces number $(\mathrm{N}=11)$. Results reported by Grips et al. ${ }^{37}$, Liu et al. ${ }^{41}$ and Ananthakumar et al. ${ }^{42}$ showed good corrosion resistance results for multilayer coatings with a total thickness up to $2 \mu \mathrm{m}$, interlayer thickness of about 20-30 nm and interfaces number ranging from $45<\mathrm{N}<430$.

Regardless the three studied conditions have different surfaces, $\mathrm{E}_{\text {corr }}$ capacitance $\mathrm{C}$, and exponential factor $n$ values are similar (Tables 1,2). This result can be explained based on the assumption that these measures are determined by $\mathrm{TiO}_{2}$ thin film, which grown on each studied surface condition. ${ }^{20}$

For a better understanding of the PVD surface treatment effects, we compare the results of uncoated, TiN and TiAlN/ TiAlCrN coated Ti-6Al-4V alloy. The results were discussed in terms of protective efficiency and compared with corrosion tests that used other corrosion solutions.

Equation 4 calculates the efficiency of the protective coatings:

$$
\operatorname{Pi}(\%)=\left[1-\left(\frac{i_{\text {corr }}}{i_{\text {corr }}^{o}}\right)\right] \times 10
$$

where $i_{\text {corr }}$ is the corrosion current density at coated condition and $i_{\text {corr }}^{\mathrm{o}}$ is the corrosion current density at uncoated condition $^{43}$.

Table 4 lists the coatings protective efficiency.

Based on Table 4 it can be seen that the TiN based coating showed better protective efficiency levels and offer better protection to the uncoated Ti-6Al-4V alloy.

Table 5 displays the main results obtained from Ti-6Al$4 \mathrm{~V}$ corrosion tests in $\mathrm{HCl}^{9}$ and $\mathrm{NaCl}^{10}$.

Based on Table 5, a comparison between each condition gives an idea about the corrosion properties of Ti-6Al-4V
Table 4. Efficiency of the protective coatings in $\mathrm{NaOH}$ solution (\%).

\begin{tabular}{ccc} 
& TiN & TiAlN \\
\hline $25^{\circ} \mathrm{C}$ & 66 & - \\
$60^{\circ} \mathrm{C}$ & 41 & 41 \\
\hline
\end{tabular}

alloy. At all conditions, increasing temperature decreased corrosion resistance. The corrosion resistance at uncoated and coated condition behaved as follows in each solution: $\mathrm{NaCl}>\mathrm{NaOH}>\mathrm{HCl}$. The same analysis can be done based on coating type, thus, the corrosion behavior would alter as follows: TiN > TiALN/TiAlCrN > uncoated Ti-6Al-4V alloy. But, some cases have singularities. First, at $25^{\circ} \mathrm{C}$, it is possible to see that $i_{\text {corr }}$ hide the corrosion resistance variation between the solutions. This corrosion resistance difference appears on impedance measures. Second, in TiAlN/TiAlCrN coated condition at $25^{\circ} \mathrm{C}$, impedance measured in $\mathrm{NaOH}$ solution showed a lower value than impedance measured in $\mathrm{HCl}$ solution. According to Soliman ${ }^{44}$, aluminum reacts with $\mathrm{OH}^{-}$producing aluminate ion and providing higher corrosive activity. This could explain the lower corrosion resistance in $\mathrm{NaOH}$ solution that is less aggressive than $\mathrm{HCl}$ (once $\mathrm{NaOH}$ has no chloride ion and titanium behaves passively in alkaline medium). At last, in polarization test at $60^{\circ} \mathrm{C}, \mathrm{i}_{\text {corr }}$ measured in $\mathrm{NaOH}$ solution are slightly lower than $\mathrm{i}_{\text {corr }}$ measured in $\mathrm{NaCl}$ solution. This trend distinguishes from impedance analyses (impedance measured in $\mathrm{NaOH}$ solution are higher than impedance measured in $\mathrm{NaCl}$ solution). Increasing temperature favors localized corrosion through the coating pores or pitting formation on surface at uncoated condition. Localized corrosion increases current density and can affect $\mathrm{i}_{\text {corr }}$ measures. Impedance measure took place at corrosion potential, without disturbance and film destabilization, thus, give a more reliable result.

\section{Conclusion}

This paper concludes a series of analyzes about Ti-6Al-4V corrosion behavior treated superficially. The studies explore the behavioral corrosion titanium alloy, in different solutions, temperatures and coatings chemical compositions. This is an unpublished work that investigated the influence of microstructure, chemical reactions and temperature on the corrosion resistance of the alloy Ti-6Al-4V. The main conclusions were:

- impedance measures are more reliable than $\mathrm{i}_{\text {corr }}$, once the later one gives a measure without disturbance;

- multilayers coating are, in general, more resistant than single coatings, but that rule change with the microstructure. Microstructural parameters like thickness, intelayers number and aluminum amount impact on coating corrosion behavior. The multilayer studied in the present work suffered spallation after polarization at all conditions studied;

- Increasing temperature favors pitting corrosion at uncoated condition and localized corrosion through the pores at coated conditions when chloride ions were present; 
Table 5. Main results obtained from Ti-6Al-4V corrosion tests in $\mathrm{HCl}^{9}$ and $\mathrm{NaCl}^{10}$.

\begin{tabular}{|c|c|c|c|c|}
\hline Temperature $\left({ }^{\circ} \mathrm{C}\right)$ & & Ti-6Al-4V & $\mathrm{TiN}$ & TiAlN \\
\hline \multirow{8}{*}{25} & $\mathrm{i}_{\text {corr }}\left(\mathrm{A} / \mathrm{cm}^{2}\right)$ & & & \\
\hline & $\mathrm{HCl}$ & $10^{-5}$ & $10^{-7}$ & $10^{-7}$ \\
\hline & $\mathrm{NaOH}$ & $10^{-7}$ & $10^{-7}$ & $10^{-7}$ \\
\hline & $\mathrm{NaCl}$ & $10^{-7}$ & $10^{-7}$ & $10^{-7}$ \\
\hline & $\mathrm{R}\left(\Omega . \mathrm{cm}^{2}\right)$ & & & \\
\hline & $\mathrm{HCl}$ & $10^{3}$ & $4.7 \times 10^{5}$ & $10^{5}$ \\
\hline & $\mathrm{NaOH}$ & $10^{4}$ & $8.9 \times 10^{5}$ & $10^{4}$ \\
\hline & $\mathrm{NaCl}$ & $10^{5}$ & $10^{7}$ & $10^{7}$ \\
\hline \multirow{8}{*}{60} & $\mathrm{i}_{\text {corr }}\left(\mathrm{A} / \mathrm{cm}^{2}\right)$ & & & \\
\hline & $\mathrm{HCl}$ & $10^{-4}$ & $2.4 \times 10^{-6}$ & $2.5 \times 10^{-6}$ \\
\hline & $\mathrm{NaOH}$ & $2.2 \times 10^{-6}$ & $1.3 \times 10^{-6}$ & $1.3 \times 10^{-6}$ \\
\hline & $\mathrm{NaCl}$ & $3.7 \times 10^{-6}$ & $2.0 \times 10^{-6}$ & $1.4 \times 10^{-6}$ \\
\hline & $\mathrm{R}\left(\Omega \cdot \mathrm{cm}^{2}\right)$ & & & \\
\hline & $\mathrm{HCl}$ & - & - & - \\
\hline & $\mathrm{NaOH}$ & $10^{4}$ & $10^{4}$ & $10^{4}$ \\
\hline & $\mathrm{NaCl}$ & $10^{5}$ & $10^{6}$ & $10^{6}$ \\
\hline
\end{tabular}

- Increasing temperature decreases corrosion resistance at all studied conditions.

\section{Acknowledgments}

The authors would like to acknowledge FAPESP (Fundação de Amparo à Pesquisa do Estado de São Paulo) for their continued financial support (Process 2011/00511-0; 2013/00885-2; 2013/00886-9).

\section{References}

1. Chung KH, Liu GT, Duh JG, Wang JH. Biocompatibility of a titanium-aluminum nitride film coating on a dental alloy. Surface and Coatings Technology. 2004;188-189:745-749.

2. Donachie MJ Jr. Understanding the Metallurgy of Titanium Crystal Structure and Alloy Types. In: Donachie MJ Jr. Titanium: A Technical Guide. $2^{\text {nd }}$ ed. Materials Park: ASM International; 2000. p. 13-24.

3. Cui C, Hu B, Zhao L, Liu S. Titanium alloy production technology, market prospects and industry development. Materials \& Design. 2011;32(3):1684-1691.

4. Gurrappa I. Characterization of titanium alloy Ti-6Al-4V for chemical, marine and industrial applications. Materials Characterization. 2003;51(2-3):131-139.

5. Subramanian B, Muraleedharan CV, Ananthakumar R, Jayachandran M. A comparative study of titanium nitride (TiN), titanium oxy nitride (TiON) and titanium aluminum nitride (TiAlN), as surface coatings for bio implants. Surface and Coatings Technology. 2011;205(21-22):5014-5020.

6. Cubillos GI, Romero E, Alfonso JE. Influence of corrosion on the morphology and structure of $\mathrm{ZrO}_{x} \mathrm{Ny}-\mathrm{ZrN}$ coatings deposited on stainless steel. Materials Chemistry and Physics. 2016;176:167-178.
7. Fenker M, Balzer M, Büchi RV, Jehn HA, Kappl H, Lee JJ. Deposition of $\mathrm{NbN}$ thin films onto high-speed steel using reactive magnetron sputtering for corrosion protective applications. Surface and Coatings Technology. 2003;163-164:169-175.

8. Ma G, Lin G, Gong S, Liu X, Sun G, Wu H. Mechanical and corrosive characteristics of Ta/TaN multilayer coatings. Vacuum. 2013;89:244-248.

9. Oliveira VMCA, Aguiar C, Vazquez AM, Robin A, Barboza MJR. Improving corrosion resistance of $\mathrm{Ti}-6 \mathrm{Al}-4 \mathrm{~V}$ alloy through plasma-assisted PVD deposited nitride coatings. Corrosion Science. 2014;88:317-327.

10. Oliveira VMCA, Vazquez AM, Aguiar C, Robin A, Barboza MJR. Protective effect of plasma-assisted PVD deposited coatings on Ti-6Al-4V alloy in $\mathrm{NaCl}$ solutions. Materials \& Design. 2015;88:1334-1441.

11. Pourbaix M. Atlas of Electrochemical Equilibria in Aqueous Solution. $2^{\text {nd }}$ ed. Houston: National Association of Corrosion Engineers; 1974. p. 219.

12. Lunarska E, Ageeva N, Michalski J. Corrosion resistance of plasma-assisted chemical vapour deposition (PACVD) TiNcoated steel in a range of aggressive environments. Surface and Coatings Technology. 1996;85(3):125-130.

13. Mentus S, Pjescic J, Blagojevic N. Investigation of titanium corrosion in concentrated $\mathrm{NaOH}$ solutions. Materials and Corrosion. 2002;53(1):44-50.

14. Shahba RMA, Ahmed ASI, El-Shenawy AE, Ghannem WA, Tantawy SM. Effect of Natural Products on the Corrosion of Titanium and Its Alloy in $\mathrm{NaOH}$ Solutions. International Journal of Chemistry. 2012;4(1):30-38.

15. Rossi S, Fedrizzi L, Bacci T, Pradelli G. Corrosion behaviour of glow discharge nitrided titanium alloys. Corrosion Science. 2003;45(3):511-529. 
16. Hefny MM, Mazhar AA, El-Basiouny MS. Dissolution behavior of titanium oxide in $\mathrm{H}_{2} \mathrm{SO}_{4}$ and $\mathrm{NaOH}$ from impedance and potential measurements. British Corrosion Journal. 1982;17(1):38-41.

17. Pohrelyuk IM, Fedirko VM, Tkachuk OV, Proskurnyak RV. Corrosion resistance of Ti-6Al-4V alloy with nitride coatings in Ringer's solution. Corrosion Science. 2013;66:392-398.

18. Liu C, Bi Q, Leyland A, Matthews A. An Electrochemical Impedance Spectroscopy Study of the Corrosion Behaviour of PVD Coated Steels in $0.5 \mathrm{~N} \mathrm{NaCl}$ Aqueous Solution: Part II.: EIS interpretation of corrosion behavior. Corrosion Science. 2003;45(6):1257-1273.

19. Moisel M, de Mele MAFL, Müller WD. Biomaterial Interface Investigated by Electrochemical Impedance Spectroscopy. Advanced Engineering Materials. 2008;10(10):B33-B46.

20. Rudenja S, Pan J, Wallinder IO, Leygraf C, Kulu P. Passivation and Anodic Oxidation of Duplex TiN Coating on Stainless Steel. Journal of The Electrochemical Society. 1999;146(11):40824086.

21. Assis SL, Wolynec S, Costa I. Corrosion characterization of titanium alloys by electrochemical techniques. Electrochimica Acta. 2006;51(8-9):1815-1819.

22. Alves VA, Reis RQ, Santos ICB, Souza DG, Gonçalves TF, Pereira-da-Silva MA, et al. In situ impedance spectroscopy study of the electrochemical corrosion of $\mathrm{Ti}$ and $\mathrm{Ti}-6 \mathrm{Al}-4 \mathrm{~V}$ in simulated body fluid at $25^{\circ} \mathrm{C}$ and $37^{\circ} \mathrm{C}$. Corrosion Science. 2009;51(10):2473-2482.

23. Manhabosco TM, Tamborim SM, Santos CB, Müller IL. Tribological, electrochemical and tribo-electrochemical characterization of bare and nitrided Ti6A14V in simulated body fluid solution. Corrosion Science. 2011;53(5):1786-1793.

24. Kalisz M, Grobelny M, Zdrojek M, Świniarski M, Judek J. Determination of structural, mechanical and corrosion properties of titanium alloy surface covered by hybrid system based on graphene monolayer and silicon nitride thin films. Thin Solid Films. 2015;583:212-220.

25. Joska L, Fojt J, Hradilova M, Hnilica F, Cvrcek L. Corrosion behaviour of TiN and $\mathrm{ZrN}$ in the environment containing fluoride ions. Biomedical Materials (Bristol, England). 2010;5(5):054108.

26. Liu W, Zhou Q, Li L, Wu Z, Cao F, Gao Z. Effect of alloy element on corrosion behavior of the huge crude oil storage tank steel in seawater. Journal of Alloys and Compounds. 2014;598:198-204.

27. Utomo WB, Donne SW. Electrochemical behaviour of titanium in $\mathrm{H}_{2} \mathrm{SO}_{4}-\mathrm{MnSO}_{4}$ electrolytes. Electrochimica Acta. 2006;51(16):3338-3345.

28. Souza KA, Robin A. Influence of concentration and temperature on the corrosion behavior of titanium, titanium- 20 and $40 \%$ tantalum alloys and tantalum in sulfuric acid solutions. Materials Chemistry and Physics. 2007;103(2-3):351-360.

29. Balamurugan A, Balossier G, Michel J, Ferreira JMF. Electrochemical and structural evaluation of functionally graded bioglass-apatite composites electrophoretically deposited onto Ti6A14V alloy. Electrochimica Acta. 2009;54(4):1192-1198.

30. Barranco V, Escudero ML, García-Alonso MC. 3D, chemical and electrochemical characterization of blasted TI6A14V surfaces: its influence on the corrosion behaviour. Electrochimica Acta. 2007;52(13):4374-4384.

31. Vasilescu C, Drob P, Vasilescu E, Demetrescu I, Ionita D, Prodana $\mathrm{M}$, et al. Characterisation and corrosion resistance of the electrodeposited hydroxyapatite and bovine serum albumin/ hydroxyapatite films on Ti-6Al-4V-1Zr alloy surface. Corrosion Science. 2011;53(3):992-999.

32. Contu F, Elsener B, Böhni H. Serum effect on the electrochemical behaviour of titanium, Ti6Al4V and Ti6Al7Nb alloys in sulphuric acid and sodium hydroxide. Corrosion Science. 2004;46(9):22412254 .

33. Delgado-Alvarado C, Sundaram PA. A study of the corrosion behavior of gamma titanium aluminide in $3.5 \mathrm{Wt} \% \mathrm{NaCl}$ solution and seawater. Corrosion Science. 2007;49(9):3732-3741.

34. Geetha M, Mudali UK, Gogia AK, Asokamani R, Raj B. Influence of microstructure and alloying elements on corrosion behavior of Ti-13Nb-13Zr alloy. Corrosion Science. 2004;46(4):877-892.

35. Kumar S, Narayanan TSNS, Raman SGS, Seshadri SK. Thermal oxidation of Ti6A14V alloy: microstructural and electrochemical characterization. Materials Chemistry and Physics. 2010;119(1-2):337-346.

36. Wang CX, Wang M, Zhou X. Nucleation and growth of apatite on chemically treated titanium alloy: an electrochemical impedance spectroscopy study. Biomaterials. 2003;24(18):3069-3077.

37. Grips VKW, Barshilia HC, Selvi VE, Kalavati, Rajam KS. Electrochemical behavior of single layer $\mathrm{CrN}$, TiN, TiAlN coatings and nanolayered TiAlN/CrN multilayer coatings prepared by reactive direct current magnetron sputtering. Thin Solid Films. 2006;514(1-2):204-211.

38. Liu C, Bi Q, Matthews A. EIS comparison on corrosion performance of PVD TiN and $\mathrm{CrN}$ coated mild steel in $0.5 \mathrm{~N} \mathrm{NaCl}$ aqueous solution. Corrosion Science. 2001;43(10):1953-1961.

39. Wan GJ, Huang N, Leng YX, Chen JY, Wang J, Sun H. TiN and TI-O/TiN films fabricated by PIII-D for enchancement of corrosion and wear resistance of Ti-6Al-4V. Surface and Coatings Technology. 2004;186(1-2):136-140.

40. Kovalev AI, Wainstein DL, Rashkovskiy AY, Fox-Rabinovich GS, Yamamoto K, Veldhuis S, et al. Impact of Al and Cr alloying in TiN-Based PVD coatings on cutting performance during machining of hard to cut materials. Vacuum. 2009;84(1):184-187.

41. Liu C, Chu PK, Lin G, Yang D. Effects of Ti/TiN multilayer on corrosion resistance of nickel-titanium orthodontic brackets in artificial saliva. Corrosion Science. 2007;49(10):3783-3796.

42. Ananthakumar R, Subramanian B, Kobayashi A, Jayachandran M. Electrochemical corrosion and materials properties of reactively sputtered TiN/TiAlN multilayer coatings. Ceramics International. 2012;38(1):477-485.

43. Yoo YH, Le DP, Kim JG, Kim SK, Vinh PV. Corrosion behavior of TiN, TiAlN, TiAlSiN thin films deposited on tool steel in the 3.5 wt.\% $\mathrm{NaCl}$ solution. Thin Solid Films. 2008;516(11):35443548 .

44. Soliman HN. Influence of 8-hydroxyquinoline addition on the corrosion behavior of commercial $\mathrm{Al}$ and $\mathrm{Al}-\mathrm{HO} 411$ alloys in $\mathrm{NaOH}$ aqueous media. Corrosion Science. 2011;53(9):29943006. 